\title{
Steric Effect of Methyl Group in Regioselective Tritiation of Toluamides
}

\author{
Kunio OOHASHI and Tomonari SugANO \\ Laboratory of Radiopharmaceutical Chemistry, \\ Faculty of Pharmaceutical Sciences, Chiba University \\ Yayoi, Inage-ku, Chiba-shi 263, Japan
}

Received January 5, 1995

\begin{abstract}
Tritiation by the hydrogen isotope exchange in toluamides with $\mathrm{HTO}$ was studied in the presence of $\mathrm{RhCl}_{3} \cdot 3 \mathrm{H}_{2} \mathrm{O}$ as a catalyst. It was established by chemical degradation that the exchange reaction occurred with virtually $100 \%$ regioselectivity at the o-position $(s)\left(C_{2}\right.$ and $C_{6}$ positions $)$ of all the toluamides. The methyl group was not tritiated. The exchange in m-toluamide was very strongly hindered at the $C_{2}$ position between the methyl and the amido group. The exchange at the $C_{6}$ position was more strongly prevented in o-toluamide than in m-toluamide. These findings are explained on the basis of the steric effect of the methyl group in agreement with the previously suggested mechanism that the exchange proceeds via initial coordination of the substrate compound to rhodium(III) chloride trihydrate.
\end{abstract}

Key Words : toluamide, tritiation, regioselectivity, tritiated water, rhodium (III) chloride

\section{Introduction}

$\mathrm{RhCl}_{3} \cdot 3 \mathrm{H}_{2} \mathrm{O}$ catalyzed hydrogen isotope exchange with $\mathrm{HTO}$ or $\mathrm{D}_{2} \mathrm{O}$ occurs at the $o$ positions of aromatic amides, amines, carboxylic acids, and anilides with high regioselectivity ${ }^{1-8)}$, in contrast with the exchange occurring at the various positions of aromatic rings according to substituents in the presence of acids, metals, or even with metal complexes as the catalyst ${ }^{9)-12}$. In an early stage, the present regioselective exchange reaction was studied with $\mathrm{D}_{2} \mathrm{O}$ from a synthetic viewpoint $^{1)-3)}$. The location of heavy hydrogen was determined by NMR. Recently, several studies concerning the mechanism of the present exchange were reported with $\mathrm{HTO}^{4)-8}$. Information on regioselectivity was given by chemical degradation. The action of benzoate ions in the exchange reaction was revealed on the basis of experimental results with benzoic acid, its alkali metal salts, and methyl benzoate ${ }^{5)}$. Methyl benzo- ate was not tritiated. Experimental data given with various anilides as substrates showed electronic and steric effects by acyl groups ${ }^{6}$ and an electronic effect by the para-substituent on the extent of tritium incorporation ${ }^{7}$. The action of carboxylate ions and the former effects led us to the mechanism that the present exchange was initiated via coordination of the carboxylate ion or the nitrogen atom of anilides to the rhodium (III) catalyst. The latter electronic effect gave the result that the electron-withdrawing substituent promoted the exchange reaction. A plausible mechanism provided on the basis of the result was that tritiation proceeded by the $\mathrm{T}-$ for- $\mathrm{H}$ exchange between $\mathrm{C}^{-} \mathrm{H}^{\delta+}$ at the o-positions of substrate molecules and $\mathrm{O}^{-} \mathrm{T}^{\delta+}$ of HTO as a ligand of rhodium(III). This mechanism was in accord with experimental results with $\alpha$-phenylacetamide having active methylene hydrogens ${ }^{8}$. Rhodium complexes formed by carboxylic acids or carboxamides ${ }^{13)}$ and complexes containing both 
pyridine and chlorine co-ordinated to rhodium (III) ${ }^{14)}$ have been reported.

As described above, the steric effect of the acyl group was already reported with various anilides ${ }^{6)}$. Lockley suggested steric inhibition of labeling by the meta-substituent in a similar rhodium(III) chloride catalyzed hydrogen isotope exchange of several meta-substituted benzoic acids $^{1), 15)}$. The situations encouraged the authors to obtain more detailed information on the steric effect of the substituent bounded to the benzene ring with the three isomers of toluamide.

\section{Experimental}

Reagent grade $p$-toluamide was obtained from Wako Pure Chemical Industries, Ltd. and $o$ - and $m$-toluamides were, also in reagent grade, purchased from Aldrich Chemical Company, Inc. They were purified by repeated crystallization. Calcd for toluamide: C: 71.09; H: 6.71; N: 10.36 . Found for $o$-toluamide: C: $70.97 ; \mathrm{H}: 6.67 ; \mathrm{N}$ : 10.65. Found for $m$-toluamide: C:70.86; $\mathrm{H}: 6.60$; $\mathrm{N}: 10.39$. Found for $p$-toluamide: $\mathrm{C}: 71.25 ; \mathrm{H}$ : 6.66; N: 10.34. Reagent grade rhodium(III) chloride trihydrate was purchased from Wako Pure Chemical Industries, Ltd. $N, N$-Dimethylformamide(DMF) of HPLC grade was obtained from Aldrich Chemical Company, Inc. Tritiated water (925 MBq $\mathrm{g}^{-1}$ ) was of DuPont/NEN Research Products and used after dilution with distilled water. The specific activity was determined by using $\left[{ }^{3} \mathrm{H}\right]$ hexadecane obtained Amersham International Public Limited Company (hereafter abbreviated as Amersham) as a radioactivity standard.

The substrate toluamide $(1.2 \mathrm{mmol})$, rhodium (III) chloride trihydrate $(158 \mathrm{mg})$, and tritiated water $(0.6 \mathrm{ml})$ were dissolved in $3 \mathrm{ml}$ of DMF. Then $0.6 \mathrm{ml}$ portions of the mixture were heated in five V-vials at $105-107^{\circ} \mathrm{C}$ for $11 \mathrm{~h}$, which was a long time enough for tritium incorporation to level off. After cooling, isolation and purification of the substrate compounds were carried out in similar procedures to those described elsewhere ${ }^{6}$. To examine the intramolecular location of tritium, derivatives were synthesized from the parent toluamides. The location was established by comparing the specific activities among the parent compound and their derivatives. They were purified by repeated crystallization to be a constant count rate. A control experiment without $\mathrm{RhCl}_{3}$. $3 \mathrm{H}_{2} \mathrm{O}$ was carried out for $p$-toluamide and then tritium incorporation to the molecule was not observed. Radioactivity of tritium was measured in a toluene-based scintillator (PPO: $4 \mathrm{~g}$ and DMPOPOP: $0.2 \mathrm{~g} \mathrm{dm}^{-3}$ ) or in ACS II scintillator from Amersham by an Aloka liquid scintillation system model 3050. Each sample, except those of very low specific activities, was counted for a period sufficient to reduce the standard deviation to $0.5 \%$ or less at 2 sigma confidence level. The specific activity of tritium labeled compounds was determined from the count rate as described elsewhere ${ }^{16)}$.

\section{Results and Discussion}

First it is established by chemical degradation that the present rhodium(III) chloride catalyzed tritiation occurred at the o-position(s) of the toluamides with high regioselectivity. Figure 1 shows the synthetic schemes of derivatives from the parent toluamides. The arrows in the schemes indicate the original $o$-position(s) of the parent toluamides and the hyphenate figures below compounds stand for their numbers. The tritium labeled parent toluamides were repeatedly crystallized from water to be a constant count rate to remove the labile tritium of the amino group by exchange with light hydrogen of water as well as impurities which may still remain after column chromatographic treatment. The specific activities of the parent toluamides and their derivatives are summarized in Table 1 . In the magnitude of the specific activities of both the tolu- 


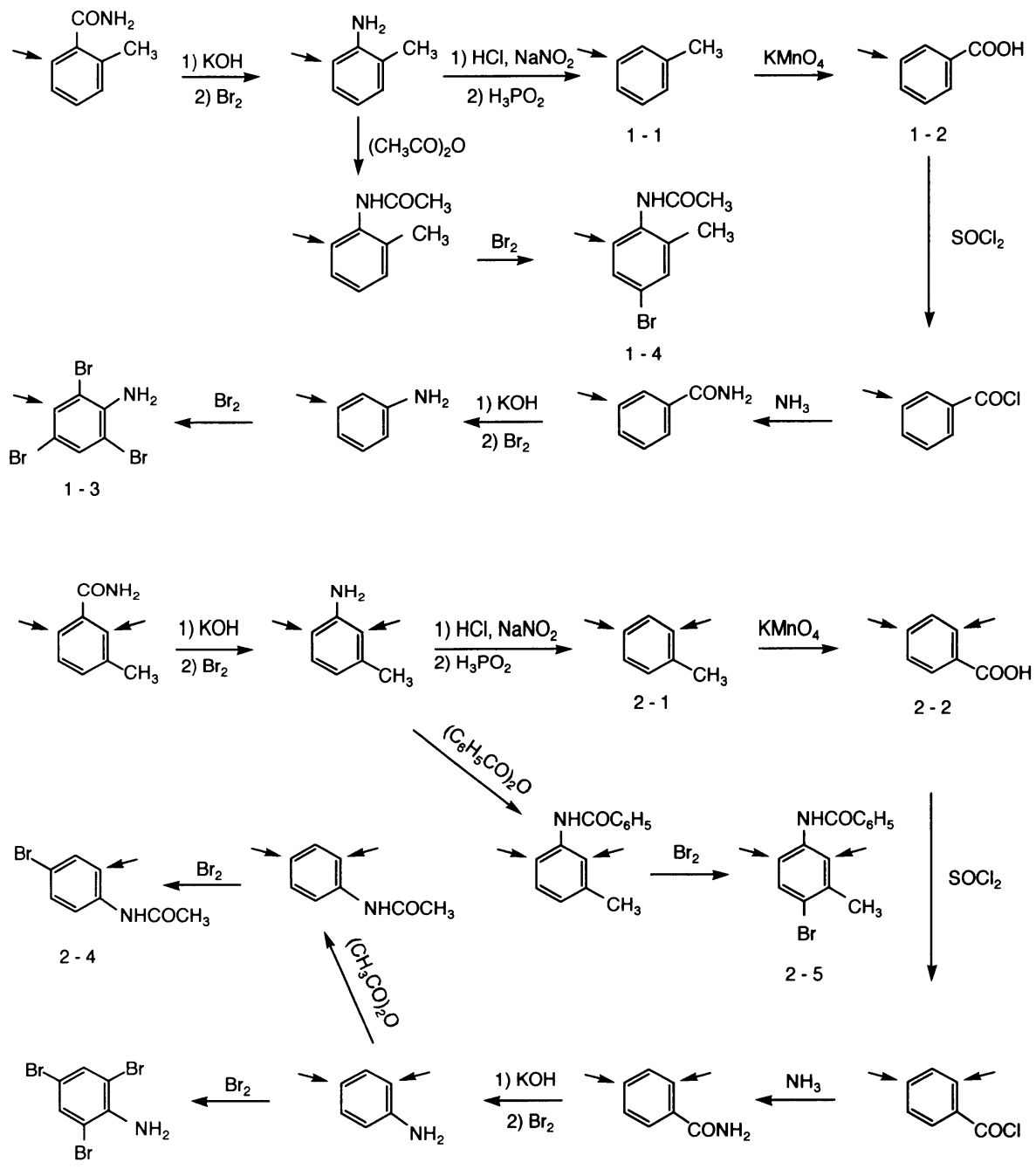
$2-3$

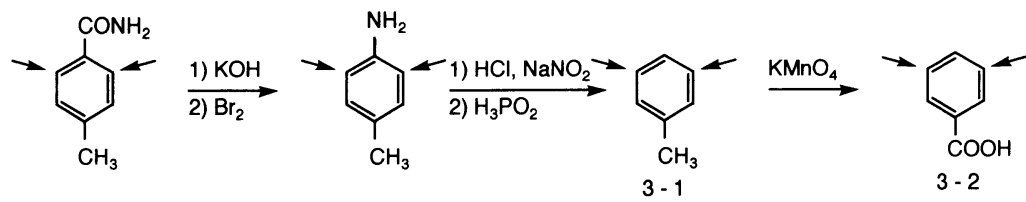

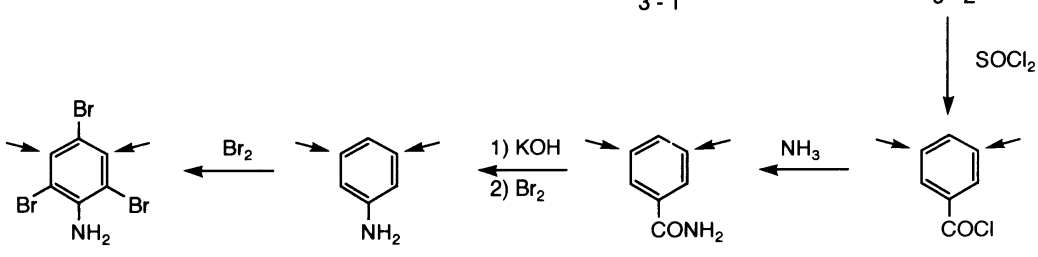
$3-3$

Fig. 1 Synthetic schemes of derivatives. 
Table 1 Specific activities of parent toluamides and their derivatives

\begin{tabular}{|c|c|c|c|}
\hline \multirow{2}{*}{$\begin{array}{c}\text { Parent } \\
\text { compound }\end{array}$} & \multirow{2}{*}{ Derivative } & \multicolumn{2}{|c|}{$\begin{array}{l}\text { Specific activity } \\
\quad\left(\times 10^{7} \mathrm{~Bq}\right)\end{array}$} \\
\hline & & Run 1 & Run 2 \\
\hline \multirow[t]{5}{*}{$o$-Toluamide } & & $7.84^{*}$ & 6.59 \\
\hline & $1-1$ & 7.84 & 6.59 \\
\hline & $1-2$ & 7.90 & 6.56 \\
\hline & $1-3$ & 7.91 & 6.55 \\
\hline & $1-4$ & 7.85 & 6.64 \\
\hline \multirow[t]{6}{*}{$m$-Toluamide } & & 45.7 & 43.4 \\
\hline & $2-1$ & 45.7 & 43.4 \\
\hline & $2-2$ & 45.4 & 43.8 \\
\hline & $2-3$ & $* *$ & $* *$ \\
\hline & $2-4$ & 2.39 & 2.42 \\
\hline & $2-5$ & 45.3 & 43.3 \\
\hline \multirow[t]{4}{*}{$p$-Toluamide } & & $132^{*}$ & 114 \\
\hline & $3-1$ & 132 & 114 \\
\hline & $3-2$ & 133 & 114 \\
\hline & $3-3$ & 132 & 114 \\
\hline
\end{tabular}

*1 Specific activity of HTO : $209 \mathrm{MBq}^{-1}$ for asterisked runs and $182 \mathrm{MBq} \mathrm{\textrm {g } ^ { - 1 }}$ for the other runs.

2 The hyphenate numbers in the column of "derivative" stand for the derivatives of the same numbers in Fig. 1.

3 The specific activities of the parent toluamides were normalized to that of $\left[{ }^{3} \mathrm{H}\right]$ hexadecane from Amersham stated in the text. The accuracy of specific activities of the derivatives is estimated to be within $\pm 1 \%$ relative to the specific activity of the parent toluamide.

** The measured tritium activity of the corresponding sample was of a background level. This means that actually no tritiation was found in these compounds.

amides and two kinds of tritiated water shown in the table or its footnote, it is very unlikely that more than one tritium atom is contained in one molecule of the above compounds. In every run, the specific activity of toluene agreed with that of benzoic acid derived from it within the experimental error stated in the footnote below Table 1, indicating that tritiation did not occur in the methyl group of toluamide. The regioselectivity at the $o$-position of $o$-toluamide is shown by agree- ment of its specific activity with those of 1-3 and 1-4. No activity of 2-3 and no difference in the specific activities between the parent $m$-toluamide and 2-5 indicate that tritiation did not occur at the $m$ - and the $p$-position. Therefore, the specific activity of 2-4 directly gives the amount of tritium incorporated to the $\mathrm{C}_{2}$ position of $m$-toluamide. The degree of tritium incorporation to the $\mathrm{C}_{6}$ position is obtained from the difference in the specific activities between the parent compound and 2-4. The regioselectivity at the $o$-positions of $p$-toluamide is established by agreement between the specific activities of the parent compound and 3-3. Thus, in the present exchange it was shown that tritium was incorporated into the $o$-position (s) in all the toluamides with a high degree of regioselectivity.

In the experiments reported here, two kinds of tritiated water were used. The specific activities were $209 \mathrm{MBq} \mathrm{g}^{-1}$ and $182 \mathrm{MBq} \mathrm{g}^{-1}$. To compare the degree of tritium incorporation among the three parent toluamides, their specific activities were normalized to the latter specific activity of tritiated water. In Table 2 were shown the normalized specific activities and the specific activity ratios, that is, the tritium incorporation ratios of $o$ - and $m$-toluamides to $p$-toluamide (specific activity $=100$ ). The former values for all the toluamides were reproduced within $\pm 3 \%$ of the average in Runs 1 and 2. The respective incorporation ratios at the $C_{2}$ and $C_{6}$ positions were shown in the lowest column in Table 2 . The ratio for $p$ toluamide was divided in equal parts for the symmetrical $\mathrm{C}_{2}$ and $\mathrm{C}_{6}$ positions about the $\mathrm{C}_{1}-\mathrm{C}_{4}$ axis. The incorporation ratios were illustrated in Fig. 2 to make possible better understanding of the situation.

It is predicted that the extent of tritium incorporation to the $o$-positions of toluamides is influenced by both the steric obstruction and the electronic effect of the methyl group bounded to the benzene ring. Previously, we reported the 
Table 2 Normalized specific activities of toluamides and tritium incorporation ratios of $o$ - and $m$-toluamides to $p$-toluamide

\begin{tabular}{lcccc}
\hline \multicolumn{1}{c}{ Compound } & & $o$-Toluamide & $m$-Toluamide & $p$-Toluamide \\
\hline Specific activity* & Run 1 & $6.83 \times 10^{7}$ & $4.57 \times 10^{8}$ & $1.15 \times 10^{9}$ \\
$\left(\mathrm{~Bq} \mathrm{~mol}^{-1}\right)$ & Run 2 & $6.59 \times 10^{7}$ & $4.34 \times 10^{8}$ & $1.14 \times 10^{9}$ \\
\hline Tritium incorporation ratio** & & 5.8 & 39 & 100 \\
& & & & \\
- Ratio per one & C-2 & - & 2 & 50 \\
position** & C- 6 & 5.8 & 37 & 50 \\
\hline
\end{tabular}

* Values normalized to the lower specific activity (182 $\left.\mathrm{MBq} \mathrm{g}^{-1}\right)$ of HTO.

** Average values in duplicate runs.
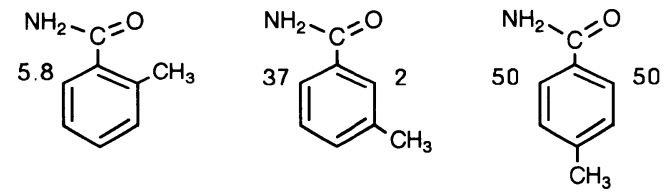

Fig. 2 Tritium incorporation ratios of $o$ - and $m$-toluamides to $p$-toluamide $(=100)$

electronic effect of substituents on the present catalytic tritiation with benzanilide and $p$ substituted benzanilides ${ }^{7}$. Tritium was found only at the $o$-positions of both the benzene rings. In that paper, substituent effects were discussed in detail and the benzoyl benzene ring was accepted as an intramolecular reference standard for tritium incorporation. The effects on tritium incorporation were compared on the basis of tritium incorporation ratios of the anilino benzene ring to the benzoyl benzene ring. Thus, the effect of the benzamido group on the adjacent $o$-positions was considered to be substantially the same for all the benzanilides. The $p$-halogen atoms increased in the order of $-\mathrm{F},-\mathrm{Cl}$, and $-\mathrm{Br}$ and the $p$-methyl group decreased the tritium incorporation ratios. These findings were explained qualitatively through the Hammett's substitution constant $(\sigma)$ which indicated the relative electron-withdrawing or electron-releasing effect of a particular substituent. By the way, the $o$-positions in the benzanilide molecule, that is, the reaction sites are the $m$-positions for the $p$-substituent. A relationship found between both the incorporation ratios and the $\sigma_{m}$ values indicated that the electronwithdrawing substituent promoted the exchange reaction at the $m$-positions. The situation is not consistent with the mechanism of electrophilic aromatic substitution. As to the reaction mechanism, it was suggested on the basis of the previous $^{6}$ and above findings that the present regioselective tritiation was initiated via coordination of the substrate compound to rhodium(III) chloride trihydrate, followed by the T-for-H exchange between $\mathrm{C}^{-} \mathrm{H}^{\delta+}$ at the $o$-positions and $\mathrm{O}^{-}$ $\mathrm{T}^{\delta+}$ of HTO as a ligand of rhodium(III) through some processes. Though an evident intermediate is not given so far, of course, here a group bounded by coordination, that is, $-\mathrm{X}: \rightarrow \mathrm{Rh}$ (III) catalyst is postulated as an attacking group on the $o$-position. The $-\mathrm{X}$ : stands for an effective functional group having a lone pair of electrons on the present exchange. The $p$-methyl group ( $\sigma_{p}$ : -0.170 ) is a little more electron-releasing and therefore will deactivate the reaction site more than the $m$-methyl group $\left(\sigma_{m}:-0.069\right)$. Thus, the tritium incorporation ratios given here seem to reflect strongly the steric obstruction by the methyl group rather than the electronic effect and in addition, a rather small electronic effect of the methyl group, in the present discussion, may be neglected.

Tritiation at both the $\mathrm{C}_{2}$ and $\mathrm{C}_{6}$ positions is free from the steric effect by the methyl group in 
p-toluamide. As shown in Fig. 2, the exchange in $m$-toluamide was strongly hindered at the $\mathrm{C}_{2}$ position between the two substituents as expected. At the $\mathrm{C}_{6}$ position, however, tritiation was moderately interfered in $m$-toluamide and unexpectedly hindered in $o$-toluamide even compared with that in $m$-toluamide. From a practical point of view, it seems be reasonable to assume that the benzene ring and the amido group almost freely rotate around the $\mathrm{C}-\mathrm{C}$ single bond between them in $p$-toluamide. On the contrary, the $o$-methyl group probably prevents the bond from freely rotating. Thus, the obstruction will be explained by the mechanism that the $o$-methyl group prevents the attacking group, $-\mathrm{CONH}_{2} \rightarrow \mathrm{Rh}$ (III) catalyst, from taking a favorable orientation to attack the $\mathrm{C}_{6}$ position. The $m$-methyl group, in contrast with the $o$-methyl group, presumably permits the attacking group to take somewhat favorable orientation for the reaction site. The situation is in accord with the above mechanism that the present tritiation proceeds via a complex formed between the amido group and rhodium(III) chloride.

Lockley labeled a variety of aromatic amides, amines, carboxylic acids, and anilides having a wide range of substituents in an early stage mainly with deuterium ${ }^{1)-3)}$ and later with tritium ${ }^{15)}$ from a synthetic viewpoint. He presented the percent reaction and the regioselectivity in deuterium labeling. The regioselectivity was shown by NMR spectroscopy. Only the specific activities of labeled compounds were given in tritium labeling without ascertaining regioselectivity. His findings agreed with ours in some cases and did not in others. Though the reason is not clear at the present stage, the complication seems to result from the reaction systems in which the steric and electronic effects act together in different degree. He suggested steric inhibition of labeling by the meta-substituent ${ }^{1), 15)}$, whereas he reported higher specific radioactivities in 3,4-dichlorobenzamide and 2-ethoxybenzamide than in benzamide ${ }^{15)}$. A similar tendency free from inhibition was shown in deuterium labeling of the 2-ethoxybenzamide ${ }^{2}$. Chemical degradation gives highly accurate data in determining of tritium location in molecules, but it is laborious, and in addition. it is only applicable to limited compounds.

\section{Acknowledgment}

The authors wish to thank Mr. Mamoru Yamamoto for assistance in drawing of the figures.

\section{References}

1) Lockley, W. J. S. : Tetrahedron Lett., 23, 38193822 (1982)

2) Lockley, W. J. S. : J. Label. Comp. Radiopharm., 21, 45-57 (1984)

3) Lockley, W. J. S. : ibid., 22, 623-630 (1985)

4) Oohashi, K., Nakamura, T. and Aoyama, Y. : J. Radioanal. Nucl. Chem. Lett., 145, 29-37 (1990)

5) Oohashi, K. and Soutome, Y. : ibid., 155, 65-73 (1991)

6) Oohashi, K. and Udo, M. : Radioisotopes, 41, 357-361 (1992)

7) Oohashi, K., Kitayama, N. and Shinoda, Y. : ibid., 41, 547-552 (1992). Oohashi, K. and Seki, T. : Abstract of papers, 36th Radiochemistry symposium of Japan, 1992, p. 240.

8) Oohashi, K. and Seki T. : J. Radioanal. Nucl. Chem. Lett., 187, 303-311 (1994)

9) Evans, E. A. : "Tritium and Its Compounds", 2nd Ed., pp. 271-318, Butterworths, London (1974)

10) Fraser, R. R. and Renaud, R. N. : J. Am. Chem. Soc., 88, 4365-4370 (1966)

11) Williams, P. G., Lukey, C. A., Long, M. A. and Garnett, J. L. : J. Label. Comp. Radiopharm., 29, 175-192 (1991)

12) Brewer, J. R., Jones, J. R., Lawrie, K. W. M., Saunders, D. and Simmonds, A. : ibid., 34, 391400 (1994)

13) Brown, J. M. and Parker, D. : J. Org. Chem., 47, 2722-2730 (1982)

14) Gillard, R. D. and Wilkinson, G. : J. Chem. Soc., 1224-1228 (1964)

15) Lockley, W. J. S. : J. Chem. Research (S), 178179 (1985)

16) Saito, T., Oohashi, K., and Morikawa, N. : Radio isotopes, 30, 596-598 (1981) 
要旨

\title{
トルアミドの位置選択的トリチウム化におけるメチル基の立体効果
}

\author{
大橋國雄，菅野智徳
}

千葉大学薬学部放射性薬品化学研究室

263 千葉市稲毛区弥生町 1-33

$\mathrm{RhCl}_{3} ・ 3 \mathrm{H}_{2} \mathrm{O}$ の存在下に $\mathrm{HTO}$ を用いてトルアミドをトリチウム化し，減成反応によりこの 水素同位体交換反応がオルト位 $\left(\mathrm{C}_{2}\right.$ および $\mathrm{C}_{6}$ 位 $)$ で高度に位置選択的に起こることを確認した。 $m$-トルアミドの二つの置換基の間の $\mathrm{C}_{2}$ 位ではトリチウム化はきわめて起こりにくく， $\mathrm{C}_{6}$ 位では トリチウム化はパラ>メタ>>オルトトルアミドの順に起こりにくくなることが見いだされた。こ れらの結果は，この反応は塩化ロジゥム（III）触媒に基質分子の官能基が非共有電子対により配位 する機構を経て進むというすでに報告された機構と矛盾することなく，メチル基の立体効果によっ て説明された。 